\title{
AN OBSERVATION OF CLASSROOM ASSESSMENT PRACTICES AMONG LECTURERS IN SELECTED MALAYSIAN HIGHER LEARNING INSTITUTIONS
}

\author{
${ }^{1}$ Charanjit Kaur Swaran Singh, ${ }^{2}$ Othman Lebar, \\ ${ }^{1}$ Napisah Kepol, ${ }^{3}$ Rafiah Abdul Rahman, \\ ${ }^{3}$ Kurotol Aini Muhammad Mukhtar \\ ${ }^{1}$ Faculty of Languages and Communication \\ ${ }^{2}$ Faculty of Education and Human Development \\ Universiti Pendidikan Sultan Idris \\ Perak, Malaysia \\ ${ }^{3}$ Institut Perguruan Tun Hussein Onn, Batu Pahat, Malaysia
}

${ }^{2}$ Corresponding author: othman@fppm.upsi.edu.my

\begin{abstract}
Purpose - The study was aimed at exploring and analysing the current assessment practices of lecturers in selected Malaysian higher learning institution classrooms. The focus was the different modes of assessment used in the classroom and to make recommendations on using a variety of assessment modes that would be well-aligned with the intended learning outcomes.

Methodology - A qualitative approach using a descriptive case study design was employed in developing the study. Subjects of the study were selected based on a voluntary basis and 15 lecturers teaching in eight programmes from two higher learning institutions participated in the study. Classroom observation was the main method of data collection, while data analysis employed thematic analysis. Each lecturer was observed twice. Three instruments were used in data collection, namely: pre-observation form, observation form and video recordings. The data was analysed through the opencoding process. The notes in the observation forms were compiled and reviewed to identify themes.
\end{abstract}


Findings - The findings revealed that the current assessment practices of the lecturers included several modes of assessment, with oral questioning and peer assessment modes being used more frequently than others. The feedback modes employed were also varied with giving comments and correcting student answers or errors as the most common modes. The results provided evidence that besides teacher assessment, peer assessment was found to be another form of assessment favoured by the lecturers during the teaching and learning process. It was used to assess student presentations, to correct peer errors, and to give feedback.

Significance - The findings were used to guide decisions on the need for assessment training for lecturers, educators and curriculum developers regarding the types of assessment modes for incorporation in teaching and learning, and also the need for assessment training that would provide lecturers with the knowledge and confidence to use a variety of assessment modes.

Keywords: Current assessment practices, modes of assessment, peer-assessment, self-assessment, questioning.

\section{INTRODUCTION}

Classroom assessment practice has received a lot of attention in recent years as it is an inseparable aspect of the teaching and learning process. Since lecturers are given the mandate for assessing instruction and student learning, there is great concern about the product and quality of their assessment. Lecturers assess students to gather information pertaining to their learning progress. Moreover, lecturers assess student learning to obtain feedback about students' understanding of the knowledge, skills and content taught and thus, to be able to identify their students' weaknesses and strengths. Lecturers explore different kinds of assessment modes and activities to tap into student understanding, or to gauge how much learning has taken place (Dunlosky et al., 2013). Assessment assists lecturers in terms of providing a record of how much new skills and knowledge have been absorbed by the students. The literature on classroom assessment has shown that the content domain in which lecturers are required to develop the assessment skill would encourage educators to focus on the process as well as the products of learning, and to 
move away from a reliance on single-test scores towards assessment that seeks to capture a variety of abilities and outcomes (Sambell, McDowell, \& Brown, 1997).

In Malaysia, the norm has been that teachers practice assessment of learning (ASLI-CPPS, PROHAM \& KITA-UKM, 2012) and now the focus has shifted to assessment for learning (AfL) so as to be able to improve and upgrade student ability (Chan, Gurnam \& Md. Rizal, 2009). Malaysian students come from different backgrounds with diverse cultures, and they have different needs based on their individual abilities (Charanjit Kaur, 2014). The humanistic philosophies believe that in order for students to perform well, all basic needs must be provided (Huitt, 2009). This would mean looking at the students' background as well as teacher's pedagogies (Oran, 2009). Therefore, the results of a single form of examination will not reflect the multiple intelligences that students have and therefore, do not reveal students' real abilities (Tunku Mohani, 2010).

Lecturers still have some confusion over the 'what' and 'how' of best classroom assessment practices. Zubairi, Sarudin, and Nordin (2008) shared their findings that Malaysian university lecturers used classroom assessment practices which incorporated paperand-pencil tests with quizzes and traditional formats such as essay writing, open-ended and also multiple choice questions. What was found lacking in Malaysian universities was the use of alternative and authentic assessments (e.g., observations, demonstrations, portfolios). This study seeks to expand the current literature on classroom assessment practices by exploring and analysing the assessment practices and skills of lecturers in relation to teaching and learning, the input they gave to students, the types of assessment used and also assessment modes.

\section{BACKGROUND OF THE STUDY}

\section{Assessment in Malaysian Higher Education: The National Context}

Education has been a key factor in Malaysia's rapid economic growth since independence in 1957, and the national government has been continuously striving and successfully providing growth 
and expansion of the nation's education system. Being driven by both industry needs and human development needs, there is a clear recognition that in the 21 st Century, at the centre of all the educational resources and programmes, quality teachers and their education are a primary factor in improved student outcomes and achievement. The government has put in efforts to change the assessment culture in the form of school-based assessment to avoid viewing students' scoring A's as a way to measure success. The universities in Malaysia should also adopt such a view and move away from the rote learning approach to teaching. Lecturers must possess effective classroom assessment implementation practices so that their students can exhibit their strengths and weaknesses appropriately.

The National Higher Education Strategic Plan 2020 and Malaysia Education Blueprint 2013-2025 have emphasised the use of assessment to promote greater active student learning to enhance their potentials. As a result, it is compulsory for all the universities in Malaysia to emphasise two key components in the structure of academic programmes which are: clear and measurable programme learning outcomes and quality assessment well-aligned with the intended outcomes. The relationship between these two components is inseparable because learning outcomes are used as a source of guidance and practice of assessment among university lecturers (Tunku Ahmad et al., 2014). The requirement to integrate measureable outcomes and well-aligned quality assessment into higher education academic programmes is governed by two sources: (a) the Malaysian Ministry of Higher Education through its Quality Assurance Division, and (b) the Malaysia Education Blueprint 2015-2025. Since its implementation, the requirement has enthused most of the public universities to design a policy to guide their academic staff classroom assessment practices and hold workshops on classroom assessment practices for their academic staff.

Transforming higher education is therefore a major reform being envisioned by the nation. The Malaysia Education Blueprint 20152025 identifies the skills students need to master to operate in a globally competitive environment. The government foresees that students must be able to thrive in an increasingly inter-connected world, and be able to lead and work effectively with others. 


\section{Purpose and Rationale of the Study}

The purpose of the study was to investigate the current assessment practices of participating lecturers. The findings from this investigation were used as a guide to determine the need for training and exposure to assessment practices not practiced by the lecturers. Related activities on assessment practice have been carried out through observation of classroom teaching and mapping out the assessment practices through analysis of instructional plans of selected courses in several academic programmes. Observations of classroom assessment practices were carried out to find out the variety of assessment and feedback modes used by the lecturers.

\section{LITERATURE REVIEW}

\section{Assessment for Learning}

The idea of assessment for learning is to use assessment to provide useful feedback to learners and lecturers in order to facilitate more effective learning outcomes. Today, the focus is more on assessment for learning rather than of learning. Assessment for Learning (AfL) is the process of seeking and interpreting evidence for use by learners and their teachers to decide students' current progress in learning, how they have learnt and how teachers can assist them by providing ongoing information on their strengths and weaknesses (ARG, 2002). The concept of AfL involves responsibilities of both teachers and students in sharing and valuing learning processes. AfL means students benefit from the assessment which does far more than simply test what they know. AfL ensures that students take part in the kinds of activities that will help them develop by providing them with guidance and feedback (Rohaya et al., 2014). According to Sadler (1989), formative assessment is specifically intended to provide feedback on performance, improve and accelerate learning while Nicole and Macfarlane-Dick (2006) claimed that feedback would strengthen students' capacity to self-regulate their own performance. 
When teachers create and involve students in an active classroom learning environment, students will tend to learn more. Students who work in collaborative groups appear more satisfied with their learning (Beckman, 1990; Chickering \& Gamson, 1991; Johnson, Johnson, \& Smith, 1991; Slavin, 1983). This is further supported by Nicol and Macfarlane-Dick (2006), who found that formative assessment can be an integral part of learning when teachers practice effective feedback at the heart of the learning process. Although it is time consuming, teachers can assist students to become aware of the learning outcomes connected with learning. Students will be aware of the learning process and take a keen interest in doing their work to attain these outcomes. As a result, students will understand that they also need to be actively involved in the learning process. For a better classroom assessment implementation, teachers' competencies should be elevated through continuous professional development in the three main components of the teaching and learning process; content, pedagogy and assessment (Rohaya et al., 2014). Teachers have to equip themselves with a sound knowledge and skills required that would enable them to create an environment, culture and practice leading to an enriched learning experience (Quilter, 1998).

A study conducted by Rohaya (2014) on assessment for learning in Malaysia revealed that teachers were unprepared for the change and found the new system challenging. They were required to learn new skills. Most of the time, they had to learn through experience and more of "on-the-job" training. Teachers need to view assessment as a vehicle for classroom practices and crucial for helping students learn. Teachers should also regard AfL as a key to professional skills (Rohaya et al., 2014). AfL should be embedded in the planning of everyday classroom activities. Learning outcomes, teaching strategies and assessment criteria should be carefully designed. Students should be informed in advance what they will learn, as well as how and why they are to be assessed (Rohaya, 2014). Teachers' daily and weekly planning should be flexible so that they can adapt in response to new information, opportunities or insights. Their planning needs to include strategies to check if students understand the goals being pursued and the criteria to be applied in assessing their work. 
Fisher, Milne, and Bull (2011) and Milne, Poyser, Williamson and Savage (2010) suggest that teachers have to create good rapport and a positive learning environment and avoid closed ended questioning in the classroom so that best practices can result in higher quality information gathered to assess students (Abbasnasab-Sardareh, \& Saad, 2013; Lamb, Orbach, Hershkowitz, Esplin, \& Horowitz, 2007; Memon, Meissner, \& Fraser, 2011). Effective questioning technique is a crucial feature of AfL which plays an essential part in student learning to improve decision-making function ability to develop reasoning (Sachdeva, 1996), challenge students' beliefs and background knowledge (Petty, 1998), and reinforce their arguments and propositions (James \& Baldwin, 1997) depending on the types of questions being asked (Ramsden, 2003). Hence teachers must avoid asking too many factual question (Lorsch \& Ronkowski, 1982) but instead emphasise more on deep-learning level (Ramsden, 2003) categories of questions. According to Black, Harrison, Lee, Marshall, and Wiliam (2003), questioning technique in an AfL classroom is not utilized just as a pedagogical tool to obtain evidence of students' understanding but it is also a means to improve their understanding.

Teachers can pose lower cognitive questions consisting of closed, knowledge, factual and recall questions. This will necessitate students to provide short responses based on what they have learned previously; in contrast, higher cognitive questions -- also referred to as referential, interpretive, evaluative and open-ended questions -require students to create their own answers and help them promote higher order thinking skills; teachers need to encourage such questions explicitly (Scoboria \& Fisico, 2013). Studies have shown that questions teachers ask in the classroom are usually procedural and factual (Bartek, 2002; Brookfield, 1987; Myrick \& Yonge, 2002; Sellappah, Hussey, Blackmore, \& McMurray, 1998). These questions do not help students increase autonomy (Choi, Land, \& Turgeon, 2008; Cohen, 1994; Ismail \& Alexander, 2005; King, 1994; King \& Rosenshine, 1993; Rosenshine, Meister, \& Chapman, 1996) nor do they fulfill the other functions of questioning such as motivating students to think, develop their reflections and interest and encourage students to ask questions (Brown \& Edmondson, 1985; Cooper, 2010). 
Assessment for learning comprises two phases. Initially a diagnostic assessment is carried out (Tunku Mohani, 2010). It is then followed by formative assessment. In the case of poor performance by certain students, remedial lessons are given so that these students can catch up with their peers in the same class. Student progress is closely monitored by the teacher. This form of assessment is conducted throughout the learning process until the time of summative assessment. As highlighted by Davies (2000), in assessment for learning, assessment is an instructional tool that promotes learning rather than an event designed solely for evaluation and grade assignment. And when students are actively involved in the assessment process (for example, peer- and self-assessment), AfL begins to look more like teaching and less like testing. In short, "assessment for learning" is concerned with obtaining feedback on learning and teaching, and utilizing this to make learning more effective and to introduce any necessary changes to teaching strategies (Tunku Mohani, 2010). Formative assessment is all about monitoring student learning to provide ongoing feedback that lecturers can use to improve their teaching and students can use to improve their learning.

Classroom assessment practice includes a wide range of approaches for the continuing evaluation of student achievement and improvement, including structured tests and quizzes; worksheets; homework assignments; and informal assessment of student participation, effort, and behavior (Martinez, Stecher, \& Borko, 2009). Judgments of student achievement based only or mostly on classroom assessment could be different across teachers such as one may value information from quizzes less than information from homework whereas another may assign the opposite weights to the same sources of information. Furthermore, teacher ideologies about assessment and the nature of learning in general can fundamentally influence their judgments of student achievement (Egan \& Archer, 1985; Llosa, 2008). For example, perceiving that every student should be tested to the same academic standards and expectations is likely to influence the approach teachers use to monitor the achievement level of their students (Martinez et al., 2009). Furthermore, teachers' beliefs about the qualified value of standardized tests as opposed to classroom assessments will obviously affect how they assess their students. Teachers who depend mostly on standardized tests 
could come to a different consensus and judgments about student achievement than those who place greater value on teacher made quizzes, effort, and classroom participation (Martinez et al., 2009). A study conducted by Tunku Ahmad et al. (2014) in thirty-three national universities in Malaysia involving 534 lecturers to find out their self-reported practices and perceived competencies in assessment for learning showed that lecturers still need to upgrade their current competencies in assessment and be supported in adopting assessment for learning. A similar study conducted by Zubairi, Sarudin and Nordin (2008) at a single public university involving a sample of 135 lecturers revealed that lecturers adhered to the traditional method of student assessment; their assessment knowledge and practice had not improved much over the years. Assessment is still very much focused on paper-and-pencil tests which are quite common among Malaysian teachers, a practice most likely adopted from years of schooling deeply rooted in traditionalist pedagogical and assessment methods (Charanjit Kaur \& Arshad, 2013).

In their study, Chan and Sidhu (2010) found that lecturers were aware of the importance of formative assessment and feedback on student learning in Malaysian universities. Students showed their interest in formative assessment conducted by their lecturers; they felt it could further develop transformative learning because of the frequent and ongoing constructive feedback received from their lecturers. These findings are supported by Craddock and Mathias (2009) who stated that formative assessment provided more opportunities in terms of learning outcomes as compared to results gained from summative assessments because most of the students were encouraged to speak up as they felt less intimidated with formative assessments. Chan and Sidhu (2010) examined authentic assessment implementation in Malaysian higher education. They identified different types of authentic assessment suitable to certain pedagogical strategies, their effects on student learning, and the appropriate procedures for conducting them. The findings indicated that alternative and authentic assessment was more acceptable to students and should therefore be viewed as an alternative to traditional standardized assessment. This was because students felt that they were given space to share their understanding and did not feel inhibited when assessed. 
University lecturers in Malaysia have to change their mind set to focus and shift the higher education paradigm from teaching to learning (Hake, 2006). Thus, investigation into lecturers' classroom assessment practices is a relevant agenda in the Malaysian higher education context. It is crucial for lecturers to know the reasons for conducting classroom assessment. Research on classroom assessment practices in higher education, however, is still in its infancy stage as there has been little "empirical evidence relating how institutions have conducted student assessment and to what effect" (Peterson \& Einarson, 2001, pp. 629-630).

According to Sebba, Deakin, Yu, Lawson and Harlen (2008), peerassessment involves students assessing each other's work, through reflection of the goals and what it means to achieve them. Peerassessment may take place in pairs or groups, where the aim may be as much the development of group processes as the promotion or judgment of individual learning. Peer-assessment has particular value in formative assessment since students ask each other questions they may be inhibited from asking their teacher, and explain things to each other using familiar language.

Gan and Hong (2010) examined the effectiveness of peer tutoring in Mathematics teaching in a Malaysian government secondary school. Findings revealed that students in the peer tutoring group had higher gain scores in the mathematics achievement tests than those in the traditional instruction group. It was reported that female students performed better in the mathematics achievement tests. Hence peer tutoring is a potentially effective instructional method in secondary mathematics teaching and learning in Malaysian schools in tandem with other existing instructional methods. Education in Malaysia is still adopting conventional lecturing pedagogy which then promotes memory-oriented learning (Ng, Bakar, Roslan, Wong, \& Rahman, 2005). Lecturers adopting the traditional teaching approach create students who are passive and incapable of comprehending knowledge delivered during lectures. Thus, in order to create opportunity for students to keep pace with their peers, lecturers should transform their teaching style to a more learner-oriented one. One of the studentcentred teaching approaches is the peer tutoring approach (Golding, Facey-Shaw, \& Tennant, 2006). Gan and Hong (2010) showed that although both groups showed high interest in learning mathematics, 
students in the peer tutoring group had significantly higher interest to learn mathematics compared to the traditional instruction group. This finding concurred with findings reported by Topping et al. (2004). They found that both tutors and tutees reported that they enjoyed learning science more after participating in the intervention. Topping et al. (2003) had earlier shown that academic self-efficacy and learning self-efficacy of students in the peer tutoring group improved after they attended tutoring programmes.

Nor Shidrah, Gilmore, and Mayo (2013) conducted a study investigating the contribution of peer evaluation in developing students' critical thinking skills. Their findings suggest that peer evaluation helped in developing critical thinking skills, thus improving academic writing performance. It was also reported that the students benefited from the collaborative learning environment either via peer evaluation or peer review activities. This was because the tools used in the activities (the rubric and the checklist) provided the students with the criteria guiding their assessment task. Putting peer evaluation into practice as a common technique in tertiary classes has been increasing and its adoption at tertiary level among lecturers is apparent (Nor Shidrah et al., 2013). Sebba et al. (2008) conducted a systematic review of research evidence on the impact of peer assessment on secondary school students. They reported that student attainment increased across a range of subject areas including increase in students' self-esteem, learning to learn, specifically goal setting, clarifying objectives, taking responsibility for learning and increased confidence.

Feedback is viewed as an important aspect in classroom assessment practice to make it effective in enhancing learning (Bell \& Cowie, 1999). Constant feedback can provide support for students and assist them to achieve future learning goals. Feedback appears in many forms from written comments in the form of grades or marks to oral responses or gestures to students. Feedback is often woven into the teaching and learning process. Lecturers can provide feedback to students at any time when the need arises. It is a crucial component in the classroom assessment practice for both lecturers and students (Bell \& Cowie, 1999). Classroom assessment practice and feedback aim at facilitating students to self-assess, reflect and monitor their learning to grow as lifelong learners. 
A study conducted by Tong (2011) exploring students' perception of and reaction to feedback in school-based assessment revealed that students did not react in the same way to assessment feedback. This occurred because not all the students had the strategies to effectively collect, organize and use feedback. The findings suggest that it was through mutual construction of achievement and improvement that students can become active participants in the classroom assessment and feedback process. Lizzio and Wilson (2007) in their study reported that students specifically value informative written feedback, but prefer balance between evaluative and informative feedback. Weaver (2006) also found that students want feedback which can give them guidance and should be related to assessment criteria, but which is not too general or too vague, or does not only dwell on the negative aspects of their work.

Tunku Ahmad et al. (2014) focused on university lecturers' conceptions about their assessment competencies in the classroom. The findings revealed that university lecturers' conceptions include practices of communicating results and feedback to students and using diverse assessment for learning methods. More importantly it was found that Malaysian university lecturers utilized assessment for learning but their practices were limited to four underlying dimensions: communicating assessment results and feedback, using diverse assessment for learning methods, recognizing unethical, illegal, and inappropriate assessment methods, and employing grading practices that integrated students' effort.

Otieno, Aloka, and Odongo (2015) investigated teachers' perceptions on oral questioning as a method of assessment of holistic development among Kenyan students. Their findings suggested that oral questioning was perceived to be effective in assessing emotional, cognitive, and social as well as personality development. However, it was also found that oral questioning was ineffective in assessing aspects such as physical growth and development, spiritual development, moral development which are crucial forms of holistic development among students.

The abovementioned related studies reveal that educators from different institutions practice different forms of assessment activities in their classrooms to bring about effective results of their students' learning. Although the assessment activities take different forms in the studies, it shows that lecturers are very appreciative of the impact 
of these assessments, finding it capable of changing instructional and assessment practices in constructive ways. One of the most favored assessment activities discussed was peer assessment. Successful peer assessment implementation requires strong student support; at the same time lecturers have to provide the correct information on the purpose, guidelines, and procedures that students have to follow. All these challenges are not insurmountable. The crucial factor in peer assessment is devising meaningful strategies and the necessary steps for students to improve their work. Lecturers must have a diversity of assessment strategies to choose from as they focus on the valued learning targets. Accuracy in assessment of the students depends on developing assessment tools. These include including performance assessment, portfolios, learning logs, selfassessment, peer-assessment, group-work assessment, and oral/ poster presentations. The real challenge for lecturers is to match the appropriate assessment method with an intended achievement target. Therefore, it is crucial for lecturers in higher learning institutions to provide sampling strategies using different assessment activities as teaching tools.

\section{Assessment Practices among Malaysian Lecturers}

Generally, diverse forms of assessment activities has been employed in teacher education programmes, including performance assessment, portfolios, learning logs, self-assessment, peerassessment, group-work assessment, and oral/poster presentations. Assessment activities can be divided into four broad categories namely Reflections, Practical Assessments, Exams/Tests and Analyses/Synthesis (Stiggins, 2005). Table 1 provides the four assessment modes and examples of assessment activities.

Table 1

Types of Assessment Modes (adapted from Stiggins, 2005)

\begin{tabular}{ll}
\hline Types of Assessment Modes & $\begin{array}{l}\text { Examples of Assessment Activities/ } \\
\text { Examples }\end{array}$ \\
\hline Reflections & $\bullet$ Reflection Logs \\
To develop the capacity for self- & - Journals \\
assessments for reflective and self- & • Case Studies \\
directed learning & - Portfolios \\
\hline
\end{tabular}




\begin{tabular}{ll}
\hline Types of Assessment Modes & $\begin{array}{l}\text { Examples of Assessment Activities/ } \\
\text { Examples }\end{array}$ \\
\hline $\begin{array}{l}\text { Practical Assessments } \\
\text { To apply theoretical concepts } \\
\text { in simulated/actual classroom } \\
\text { situations }\end{array}$ & - Micro Teaching \\
& - Field Trips \\
& - Classroom activities, exercises, oral \\
Exams/Tests & - Exams \\
To gauge the competence level in \\
theoretical foundations and content \\
knowledge & - Tests (Summative and Formative) \\
Analyses/Synthesis & Paper and pencil assessment \\
To Strengthen theory-practice & - Unit and Lesson Plans \\
linkages & - Research Papers \\
& - Class tests - Analysis of Test Items \\
\hline
\end{tabular}

\section{METHODOLOGY}

This qualitative study is an attempt to understand human experiences. Yin (2003) defined qualitative case study as an approach to research that facilitates exploration of a phenomenon within its context using a variety of data sources. This ensures that the issue is not explored through one lens, but rather a variety of lenses thus allowing for multiple facets of the phenomenon to be revealed and understood (Baxter \& Jack, 2008). Merriam (2009) stated that the qualitative method offers greater opportunities for conducting exploratory and descriptive research that uses the context and setting to search for a deeper understanding of the person being studied. According to Yin (2003) a case study design should be considered when: (a) the focus of the study is to answer "how" and "why" questions; (b) you cannot manipulate the behaviour of those involved in the study; (c) you want to cover contextual conditions because you believe they are relevant to the phenomenon under study; or (d) the boundaries are unclear between the phenomenon and context. The case is defined by Miles and Huberman (1994) as, 'a phenomenon of some sort occurring in a bounded context. The case is, "in effect, your unit of analysis' (p. 25).

Hence, for this study, a case study was chosen because the case involved investigating the current assessment practices of lecturers, more specifically investigating the modes and activities of classroom 
assessment. Case study is considered particularly appropriate for classroom research such as this that consists of detailed descriptions and in-depth study related to investigating the current assessment practices of lecturers involved. A case study approach has its advantages as it investigates an event or situation from the participants' perspective rather than from an outsider's interpretation of the context within which it occurred. In a case study approach, as in this study, the central focus is on the natural setting which was the classroom and the participants are an important source of data and information (Radnor, 2001; Silverman, 2000). Its goal was to produce a "thick description" of the meanings, perspectives and understanding by investigating the current assessment practices of lecturers in the classroom.

Classroom observation was the main method of data collection while the qualitative data obtained were thematically analysed. Observation is an important data collection method for qualitative enquiry (Merriam, 2009). Non-participant observation was conducted when the teacher educators were teaching. As mentioned before, the objective was to obtain information regarding the classroom assessment practices employed by the teacher educators that would enable us to observe the types of assessment that would emerge in the study. Through persistent observations, we were able to capture how people interacted with their surroundings based on their understandings of the world (Merriam, 2009). According to Robson (2002), observation permits researchers to watch and listen to the interaction between the teacher educators and the student teachers. The main purpose of observation is to grasp a person's motions, speaking, and unconscious behaviors expressed in a natural setting (Lincoln \& Guba, 2000; Merriam, 2009).

Observations were done during the lecturers' normal schedules. The lecturers' daily timetables were followed for conducting the observations and thus there were no class disruptions. The main focus of the observation was on the student teachers' and teacher educators' interaction in the classroom setting. We observed the teacher educators, learners (students) in their natural teaching and learning environment. An observation schedule was used to collect data. Patton (1990) in Cohen et al. (2000) saw observation data enabling the researcher to enter and understand the situation 
being described. Similarly Mertens (1998) regarded the interest of the researcher in an observation as the observation of people's behaviour as they naturally occur in terms that appear meaningful to those involved.

An observation checklist was used for gathering specific information during the observations with the teachers and teacher educators in the classrooms. There are two sections in this checklist (Section A for Demographic Information and Section B for Observation Checklist).

Three instruments were used in data collection: the classroom observation protocol (Appendix 1), pre-observation forms (Appendix 2) and classroom observations. The pre-observation form required specific information about the lesson to be observed such as the topic, learning outcomes and activities. This form was distributed to the lecturers prior to the observation sessions. The classroom observation protocol consisted of instructions and questions or notes to guide the observers in recording background information about the course and aspects of teaching and learning, including assessment strategies and activities. Each lesson observed was also video-recorded (Merriam, 2009). The video recordings were necessary for triangulation purposes, for extracting samples of assessment strategies or activities described by observers in the observation protocol, an example of a task, and for getting additional data not recorded explicitly in the observation form, such as at which point of the lesson oral questions were asked.

Fifteen lecturers from seven programmes namely Science Education, Mathematics Education, Moral Education, Physical and Health Education, TESL (Primary), TESL (Secondary), and Early Childhood Education were involved in the observation and had participated in the study as shown in Table 2 . All the lecturers were teaching first semester students during the period of observation, the sole criterion for their selection in the study. The lecturers were contacted by telephone and email to invite them to participate in the study. Once agreement was obtained from the lecturers, arrangements were made to observe their classes. Each lecturer was observed twice. The observations were carried out during Weeks $4-6$ and Weeks $9-12$ of the first semester during the 2014/2015 
academic year. Each lesson lasted from one to three hours. A total of twenty-nine lessons were observed involving forty-four hours of observation.

Table 2

Programmes and Courses observed

\begin{tabular}{|c|c|c|c|c|}
\hline PROGRAMMES & COURSES & $\begin{array}{c}\text { No. of } \\
\text { observations }\end{array}$ & $\begin{array}{l}\text { No of } \\
\text { lecturers } \\
\text { involved }\end{array}$ & $\begin{array}{c}\text { No of } \\
\text { students } \\
\text { involved }\end{array}$ \\
\hline \multirow[t]{2}{*}{$\overline{\text { TESL }}$} & English Grammar & 2 & 1 & 25 \\
\hline & Reading Skills & 2 & 1 & \\
\hline SCIENCE & Chemistry & 2 & 1 & 32 \\
\hline \multirow[t]{2}{*}{ HISTORY } & $\begin{array}{l}\text { Prehistory and Proto- } \\
\text { History of Southeast Asia }\end{array}$ & 2 & 1 & 70 \\
\hline & $\begin{array}{l}\text { Malaysia: Malacca to } \\
\text { New Malay States }\end{array}$ & 2 & 1 & \\
\hline \multirow[t]{2}{*}{ MATHEMATICS } & Beginning Calculus & 2 & 1 & 65 \\
\hline & Linear Algebra & 2 & 1 & \\
\hline \multirow[t]{2}{*}{$\begin{array}{l}\text { PHYSICAL } \\
\& \text { HEALTH } \\
\text { EDUCATION }\end{array}$} & $\begin{array}{l}\text { Basis of Physical } \\
\text { Education and Sports } \\
\text { Science }\end{array}$ & 2 & 1 & 45 \\
\hline & Sport skills (Track) & 2 & 1 & \\
\hline \multirow[t]{2}{*}{ MORAL EDUCATION } & Akhlak Islam & 2 & 1 & 107 \\
\hline & $\begin{array}{l}\text { Introduction to Moral } \\
\text { Education }\end{array}$ & 2 & 1 & \\
\hline \multirow[t]{2}{*}{$\begin{array}{l}\text { EARLY CHILDHOOD } \\
\text { EDUCATION }\end{array}$} & $\begin{array}{l}\text { Spiritual and Moral } \\
\text { Development of Children }\end{array}$ & 2 & 1 & 50 \\
\hline & $\begin{array}{l}\text { Expression of Children's } \\
\text { Creativity }\end{array}$ & 2 & 1 & \\
\hline \multirow[t]{2}{*}{ UNIVERSITY } & Nationhood & 2 & 1 & 69 \\
\hline & Personality Development & 2 & 1 & \\
\hline
\end{tabular}

Prior to the lesson observation, the lecturers returned the preobservation form and letter of consent (Appendix 3). A separate letter of consent (Appendix 4) was also distributed to each student present for the lesson observed. The lesson and observation commenced only after the letters had been signed by the students and collected. Three observers were required for each session. Two of them recorded data in the observation form and another took care 
of the video camera.

The data were analysed through the open-coding process. This study is perceived from an emic perspective that honors the work of members of a group, rather than judging the actions from an etic or an outsider perspective (Green \& Nixon, 2002; Merriam, 2009). The notes written by the observers in the observation forms were compiled and read through to identify themes. The themes were coded using labels that represent aspects of assessment such as "assessment", "feedback", "exercises" and "oral questioning". This coding process was followed by grouping together all instances of data that depicted the aspects of assessment identified. This procedure was done to facilitate closer examination of the data under each theme to further identify categories or sub categories, if any. Instances of data that seemed to overlap were discussed and assigned to a category based on consensus.

\section{Validity}

One way of improving credibility is to reduce the researcher's biases. Data does not speak for itself. The researcher interprets it. However, no researcher can observe, measure and analyse a phenomenon without personal biases. The credibility of this study was enhanced by three strategies which are triangulation, peer-debriefing and member checking. Triangulation - involving multiple sources and methods of data collection - was employed in the study. Copies of the observational and reflective notes made by the observers were sent to the respective lecturers observed for verification. All participants received, via e-mail, a copy of the observational and reflective notes for review and clarification; transcripts were sent to the lecturers involved for verification. This allowed us to ensure that what the participants said were in fact what they meant to say. All data have been verified through this process.

Validity of findings or data is traditionally understood to refer to the correctness or precision of a research reading (Ritchie \& Lewis, 2004). To ensure validity of the findings, this study had used multiple methods in making enquiries into the same phenomenon. In this way, the data will be triangulated through various sources such as classroom observations, observational and reflective notes to ensure 
the credibility of the findings. The classroom observation data were collected through observational notes and were validated with the researchers' reflective notes and then verified by the participants (lecturers) observed. The observational and reflective notes were studied meticulously to ensure that recurring patterns/themes were discerned in order to present the holistic picture of the findings. A re-coding technique was used so that data can be checked and cross-checked several times in order to enhance possibility of new understandings.

\section{RESULTS}

\section{Oral Questioning}

The observational data revealed that one of the main assessment modes participating lecturers used was oral questioning. As expected, every lecturer used oral questions in the classes observed. As a theme, oral questions could be further categorised into two types, open and closed questions. The open questions required students to produce information which were open in nature. The questions asked were $w h$-questions using question words such as what, why and how. These questions required thinking and reflection and the responses are usually longer compared to those for closed questions. The closed questions were asked to get the students to confirm something such as a fact or proposition. Examples of this type of questions are yesno questions or tag questions. The responses elicited would usually be either "yes" or "no" or any equivalent responses (verbal or physical) showing agreement/ confirmation or disagreement/denial. In the study, there were also yes-no questions that implied an answer beyond a "yes" or "no" is required, for example, "Can you describe the chemical reaction involved?"

\section{Open Questions/Yes-No Questions}

These questions were asked to elicit responses at different levels of thinking. Some examples of the lower and higher order thinking skills from the data are given in Table 2: 
Table 2

Examples of the Lower and Higher Thinking Skills

\begin{tabular}{ll}
\hline \multicolumn{1}{c}{ Lower order thinking skills } & \multicolumn{1}{c}{ Higher order thinking skills } \\
\hline $\begin{array}{l}\text { What part of speech is that? (Obv 11b, } \\
\text { Reading Skill) (identify) }\end{array}$ & $\begin{array}{l}\text { What can you tell from the video? } \\
\text { (Obv 7b) (synthesize) }\end{array}$ \\
$\begin{array}{ll}\text { What was learned last week? (Obv 6b, } & \text { Bagaimana kamu mengenali diri } \\
\text { kamu? (Obv 2r) }\end{array}$ \\
$\begin{array}{ll}\text { History) (recall) } \\
\begin{array}{l}\text { Can you describe the chemical reaction } \\
\text { stand) }\end{array}\end{array}$ & $\begin{array}{l}\text { (How do you get to know yourself?) } \\
\text { (analyse) }\end{array}$ \\
\hline
\end{tabular}

The oral questions were asked at various points in the lessons observed. Three main teaching phases were identified in the data when the oral questions were asked: the beginning, middle and end of a lesson. Within the time frames, the questions were asked during an explanation, a task, presentation and other teaching and learning activities. Most of the questions were impromptu questions and were asked to fulfill different purposes. The purposes evident from the data could be categorised as follows:

- To review the previous lesson

The questions were asked at the beginning of the lesson and referred to the previous lesson, for example the lecturers asked students the following question:

What was learned last week? - History / Malacca to new Malay states

- $\quad$ To check students' understanding

The questions were meant to check students' understanding of reading materials that had been assigned to them or teaching content that had just been explained or discussed, for example:

What part of speech is that? - TESL/ Reading skills

- To get students' to reflect

The questions were asked to get students to reflect on content or something related to the content taught, for example: 
How do you recognise yourself?- Islamic Morals / Moral from a religious perspective

- $\quad$ To point out errors

Some questions were asked, in lieu of a comment, to point out a student's error, for example,

What part of speech is that? - TESL/ Reading skills

- To help students to explain concepts, analyse something, for example, the elements of a play, and complete their group work

The questions asked were supportive in nature in that they helped students to complete a task such as explaining and analysing concepts or to strengthen a student's answer, for example:

Can you describe the chemical reaction involved?-Science / stoichiometry

What can you tell from the video? Science / stoichiometry

In terms of whom the questions were intended for, it was either targeted at individual students or the whole class. Sometimes individual students were called upon to answer a question but when the student failed to answer it, the question would be opened to the whole group in the class.

\section{Peer Assessment}

Through the observations, peer assessment was found be another common practice among the lecturers. For example, as observed in the Moral Education course for Semester One students, it was conducted using the assessment forms prepared by the lecturers to assess the students' group presentations. The assessment form was set up based on criteria specified by the lecturer according to the coursework assigned. Peers wrote their comments in a form provided by the lecturer. However, the written comments were not shared with other students. 
In another observation, it was noted that students were involved in providing feedback on peers' presentation. Peer feedback was used to assist or correct other students' errors. For example, in the English Grammar Course for the TESL Programme, students discussed in their groups on their peer's presentations. They then provided feedback to assist their friends on certain parts of the sentence analysis that were wrongly classified. This is in line with Spiller (2012) who states that students receiving feedback from their peers can get a wider range of ideas about their work to promote development and improvement. Involving peers in the assessment will help students to become more autonomous, responsible and involved. Apart from that, giving immediate feedback enhances formative learning (ARG, 2002). Peer assessment processes can help students learn how to receive and give feedback which is an important part of most work contexts. Besides, it also encourages students to critically analyse work done by their friends or peers.

Another finding related to peer assessment was found in a class whereby feedback through oral comments was used to assess peers' presentation. This was illustrated in the Introduction to Linguistics course. Students gave feedback to their peers during pair-work presentations. The presenter also responded to the issues raised by other group members. This reflects that peers were informally evaluated for further improvement. Upon further analysis, it was found that the students were critical and analytical when asking related questions and giving comments on group presentations. This supports the view that peer assessment provides more relevant information to students as it is generated by their peers. Through this peer assessment, students were more comfortable and trusted one another in order to provide honest and constructive feedback. This provides evidence that peer assessment enables development of critical reflection skills and the ability to give constructive feedback to peers. At the same time students may gain initial feedback on their work, and in a timely manner, that they can respond to in future assignments. It will also help students to engage with and internalise the content of learning in their work. It was used for assessing students' presentations, to correct peer's errors, and to give feedback. 


\section{Feedback}

Feedback was delivered in various modes. The observation data shows that lecturers used the following modes:

i. Giving comments on students' answers, presentations or roleplay

ii. Elaborating on students presentations - providing further explanation when students faced difficulty in explaining their presentations

iii. Asking questions to get students to think and reflect on the errors made

iv. Correcting students' answers or errors

v. Reviewing students' content understanding

vi. Summarising students' answers

vii. Praising students

viii. Clarifying students' responses

ix. Rewarding students

x. Discussing students' answers in the quiz

Lecturers cited several reasons for providing feedback. Mainly, the reasons were to:

i. increase students' understanding

ii. encourage students to think and reflect further

iii. correct errors made instantly

iv. improve content presentation and delivery

Lecturer feedback had several effects on student learning. Some of the effects were:

i. improved students' understanding of the content

ii. students were able to correct their errors instantly

iii. students gained confidence in presenting their ideas

To gain multiple perspectives on students' academic development, and abilities, it was crucial for the lecturers to provide feedback and include a range of measures in the classroom activities during presentations, role-play and other modes. The lecturers felt that they wanted to make some changes in their teaching for more effective results in student learning. They wanted to get students' feedback in terms of their teaching so that they can match their teaching to the students' needs in the classroom for a more meaningful 
teaching and learning process. Lecturers often identify and share the learning experiences and expectations with the students. This practice extended by the lecturers who communicate what students should learn and the goals for their development facilitate students to acquire ownership of their learning.

\section{DISCUSSION AND CONCLUSION}

The findings revealed that the lecturers embedded both teacher and peer assessment methods into their teaching practices. A variety of assessment and feedback modes were used. Oral questioning and peer assessment were the most favoured modes for assessing while giving comments and correcting students' answers and errors were the most frequently used modes of feedback. Although the data showed a variety of modes, their distribution across lecturers was uneven with some lecturers keeping to one or two preferred modes during the two periods of observation. Lecturers need to be trained to interpret learning data so that they can make the correct decision. Peer assessment and oral questioning can be used as mechanisms for promoting self and active learning as students are in control of their own learning. They can monitor their own progress and consciously identify their own learning goals. Learning goals are achievable objectives defined by the syllabus and lecturers are responsible in imparting these goals to their students. These kinds of cases indicate the need for assessment training that will provide lecturers with the knowledge and confidence to use a variety of assessment modes. Different knowledge and abilities require different ways of assessment and lecturers who know these different ways will be able to help students more efficiently.

The implication of the study is that using peer assessment and oral questioning appeared to complement lecturers' use of instructional strategies centred on students' group work, classroom presentations and individual growth. Peer assessment and oral questioning are compatible with strategies focused on different learning styles as they allow lecturers to see new developments and directions in the teaching and learning. Findings of the study suggested that providing feedback based on students' work is crucial as this will determine the types of work required for students to move to the next stage either in the form of remedial or enrichment activity. However, careful, 
systematic and a well-organized preparation should be taken into consideration. Before the implementation, peer assessment and oral questioning should be introduced to the students in order to guide them especially if these are used as an assessment method for the first time.

The study explicitly gives recommendations for practices of assessment that educate students to monitor their own learning, promote critical thinking skills and take responsibility for learning in Malaysian universities. It does so by highlighting areas that lecturers need to consider to ensure diversity and accuracy of assessment in Malaysian tertiary education. Literature discussing the significance of assessment practices along with research evidence has revealed how assessment can function beyond just giving grades to students' performance in the classroom. More distinctively it has revealed that assessment can bring effective results in students' learning.

This study also revealed that the main assessment modes employed seemed to focus on the oral questioning and peer assessment used for assessing students' presentations, to correct peer's errors, and to give feedback. Lecturers showed their willingness to utilize different classroom assessment practices rather than concentrating on the summative grades. It is very important for educators to broaden their understandings of the purposes of classroom assessment practices beyond just ranking achievement. The findings from this study are consistent with the conception of classroom assessment practices. The purpose of assessment is to support students to learn, provide them with valued learning targets instead of focusing on ranking or grading students' achievement. The findings drawn from this study have implications for professional development in relation to new assessment workshops. Lecturers need to be trained to interpret learning data so that they can make the correct decision. With personalised professional development experiences, lecturers might be more active and have effective ways to promote classroom assessment practices in their own teaching.

As discussed in the literature by the Assessment Reform Group (ARG, 2002), assessment for learning is used to provide useful feedback to learners and lecturers in order to facilitate more effective learning outcomes. It assists students in utilising knowledge about 
the types of class work they produce to support future learning. Lecturers may be occupied with other workload when it comes to marking students' work and grading them but they should use the work to reflect on their teaching, improve their assessment tasks as well as sustaining students' growth through informative feedback. This study suggests that lecturers may need professional development assistance in order to learn a diverse range of classroom assessment practices rather than focus just on measuring student learning.

This study suggests that a comprehensible picture of classroom assessment practices and marking criteria should be explained and made available to students before assessment is conducted. The outline of the classroom assessment practices and the criteria for oral questioning and peer assessment by the lecturers are not evident in the courses taught. It is crucial for the lecturers to design their course outline; marking criteria for oral questioning and peer assessment should be precise or attached to the assessment tasks. The students need to be exposed to the explicit assessment criteria as these provide a clear guidance for both lecturers and students. Shared understandings between lecturers and students about assessment and marking criteria should be made clear. Students should be informed that their performance will be marked against explicit marking criteria. In addition, the university must provide support for the lecturers to meet these standards of the classroom assessment practices. The university should reform its assessment policy, specifically classroom assessment practices, to allow this strengthening of its educational quality.

The study recommends implementing the technique of oral questioning and peer assessment, and a variety of alternative assessment tools in Malaysian universities if we want lecturers to implement active learning and cultivate analytical and critical thinking skills. With these techniques, the lecturers can assess a wide range of student learning through the classroom assessment practices. The findings reveal that lecturers are not well-equipped with oral questioning and peer assessment methods; hence, to improve it is crucial for lecturers to explore, seek and learn techniques of assessment. They can attain and acquire ways of implementing classroom assessment practices by participating in educational assessment training and short courses. 
The findings from the study contribute to the body of literature on classroom assessment practices in tertiary education by building a foundation for understanding lecturers' perceptions and practices of classroom assessment in Malaysian public higher learning institutions.

\section{ACKNOWLEDGEMENT}

This research is part of a national study to develop a teacher model under the Niche Research Grant Scheme (NRGS) commissioned by the Ministry of Education, Malaysia.

\section{REFERENCES}

Abbasnasab-Sardareh, S., \& Saad, M. R. M. (2013). Malaysian Primary School ESL teachers. Questions during Assessment for Learning. English Language Teaching, 6(8), 1-9. doi: 10.5539/elt.v6n8p1

Assessment Reform Group. (2002). Assessment for Learning: 10

Principles. Research-based practices to guide classroom practice. London, UK: Author.

ASLI-CPPS, PROHAM, \& KITA-UKM. (2012). Education reform and process of consultation. In Education Reform in Malaysia Report (pp. 1-35). Bangi, Malaysia: Universiti Kebangsaan Malaysia Institute of Ethnic Studies.

Bartek, M. M. (2002). Paving the road to critical thinking. Understanding Our Gifted, 14(4), 10-12.

Beckman, M. (1990). Collaborative learning: Preparation for the workplace and democracy. College Teaching, 38(4), 128-133.

Bell, B., \& Cowie, B. (1999). Researching formative assessment. In

J. Loughran (Ed.), Researching teaching: Methodologies and practices for understanding pedagogy (pp. 198-214). London, UK: Falmer Press.

Black, P., Harrison, C., Lee, C., Marshall, B., \& Wiliam, D. (2003). Assessment for learning: Putting it into practice. Buckingham, UK: Open University Press.

Brookfield, S. D. (1987). Developing critical thinkers. Challenging adults to explore ways of thinking and acting. San Francisco, CA: Jossey-Bass. 
Brown, G. A., \& Edmondson, R. (1985). Asking questions. In E. C. Wragg (Ed.), Classroom teaching skills (pp. 97-120). London, UK: Croom Helm.

Chan Yuen Fook, \& Gurnam Kaur Sidhu. (2010). Authentic assessment and pedagogical strategies in Higher Education. Journal of Social Sciences, 6(2), 153-161.

Chan, Yuen Fook., Gurnam Kaur Sidhu, \& Md. Rizal Md. Yunus. (2009). School-Based Assessment Enhancing knowledge and best practices. Shah Alam, Malaysia: UPENA, UITM.

Cohen, L., Marion, L., \& Morrison, K. (2000). Reserch methods in education. (5th ed.). London: Routledge Falmer.

Cohen, E. G. (1994). Restructuring the classroom: Conditions for productive small groups. Review of Educational Research, 64, 1-35. doi: 10.3102/00346543064001001

Charanjit Kaur Swaran Singh, \& Arshad Abdul Samad. (2013). The use of portfolio as an assessment tool in the Malaysian L2 classrooms. International Journal of English Language Education, 1(1), 94-108.

Chickering, A. W., \& Gamson, Z. F. (1987). Seven principles for good practice in undergraduate education. The Wingspread Journal, 9(2).

Choi, I., Land, S. M., \& Turgeon, A. (2008). Instructor modeling and online guidance for peer questioning during online discussion. Journal of Educational Technology Systems, 36(3), 255-275. doi: 10.2190/ET.36.3.c

Craddock, D., \& Mathias, H. (2009). Assessment options in higher education. Assess Evaluate Higher Education, 3(4), 127-140. doi: 10.1080/02602930801956026

Davies, A. (2000). Making classroom assessment work. Courtenay, BC: Connections Publishing. Retrieved from www.connection spublishing.ca

Dunlosky, J., Rawson, K, A., Marsh, J, M., Nathan, M. J., \& Willingham, D. T. (2013). Improving students' learning with effective learning techniques: Promising directions from cognitive and educational psychology. doi: 10.1177/ 1529100612453266

Egan, O., \& Archer, P. (1985). The accuracy of teachers' ratings of ability: A regression model. American Educational Research Journal, 2(2), 25-34. 
Fisher, R. P., Milne, B. A., \& Bull, R. (2011). Interviewing cooperative witnesses. Current Directions in Psychological Science, 20, 16-19. doi:10.1177/096372141039682

Gan Siew Ling, \& Hong Kian Sam. (2010). The effectiveness of peer tutoring in the teaching of Mathematics. Malaysian Journal of Learning and Instruction, (7).

Golding, P., Facey-Shaw, L., \& Tennant, V. (2006, October). Effects of peer tutoring, attitude and personality on academic performance of first year introductory programming students. Paper presented at The 36th ASEE/IEEE Frontiers in Education Conference, San Diego.

Green, J. L., \& Nixon, C. N. (2002). Exploring differences in perspectives on microanalysis of classroom discourse: Contributions and concerns. Applied Linguistics, 23, 393-406.

Hake, R. (2006) Measuring teaching and learning performance: Interconnected issues. The Third International Conference on Measurement and Evaluation in Education (ICMEE). Penang, Malaysia, 13-15 February. Retrieved from http:// www.physics.indiana.edu/ hake/ICMEEk-2006.pdf

Huitt, W., \& Lutz, S. (2004). Connecting cognitive development and constructivism: Implications from theory for instruction and assessment. Constructivism in the Human Sciences, 9(1), 67-90.

Ismail, H., \& Alexander, J. (2005). Learning within scripted and non-scripted peer-tutoring session: The Malaysian context. Journal of Educational Research, 99, 67-77. doi:10.3200/ JOER.99.2.67-77

James, R., \& Baldwin, G. (1997). Tutoring and demonstrating: A guide for the University of Melbourne. Centre for the Study of Higher Education, University of Melbourne, Australia.

Johnson, D. W., Johnson, R. T., \& Smith, K. A. (1991). Cooperative learning: Increasing college faculty instructional productivity. ASHE-FRIC Higher Education Report No. 4. Washington, DC: George Washington University, School of Education and Human Development.

King, A. (1994). Guiding knowledge construction in the classroom: Effects of teaching children how to question and how to explain. American Educational Research Journal, 31(2), 338-368. doi: 10.3102/00028312031002338 
King, A., \& Rosenshine, B. (1993). Effects of guided cooperative questioning on children's knowledge construction Journal of Experimental Education, 61, 127-148. doi: 10.1080/00220973. 1993.9943857

Lamb, M. E., Orbach, Y., Hershkowitz, I., Esplin, P., \& Horowitz, D. (2007). A structured forensic interview protocol improves the quality and informativeness of investigative interviews with children: A review of research using the NICHD Investigative Interview Protocol. Child Abuse and Neglect, 31, 1201-1231. doi: 10.1016/j.chiabu.2007.03.021

Lincoln, Y. S., \& Guba, E. G. (2000). Paradigmatic controversies, contradictions, and emerging confluences. In N. K. Denzin, Y. S. Lincoln, \& E. G. Guba (Eds.), Handbook of qualitative research. Thousand Oaks, CA: Sage.

Lizzio, A. J., \& Wilson, K. L. (2007). Enhancing the effectiveness of self-managed learning groups: Understanding students? Choices and concerns. Studies in Higher Education, 31, 689-703.

Lorsch, N., \& Ronkowski, S. (1982). Teaching tips for TA's: Effective questioning enhances student learning. Instructional Development, University of California, Santa Barbara.

Llosa, L. (2008). Building and supporting a validity argument for a standards-based classroom assessment of English proficiency based on teacher judgments. Educational Measurement: Issues and Practice, 27(3), 32-42.

Malaysia Education Blueprint 2015-2025. (2015). Higher Education. Retrieved from https://www.mohe.gov.my/en/download/public/ penerbitan/pppm-2015-2025-pt/5-malaysia-educationblueprint-2015-2025-higher-education/file

Malaysian Ministry of Education. (1998). Huraian sukatan pelajaran matematik KBSM. Kuala Lumpur, Malaysia: Author.

Martinez, J. F., Stecher, B., \& Borko, H. (2009). Classroom assessment practices, teacher judgments, and student achievement in Mathematics: Evidence from the ECLS. Educational Assessment, 14, 78-102. doi: 10.1080/10627190903039429

Memon, A., Meissner, C. A., \& Fraser, J. (2011). The cognitive interview: A meta-analytic review and study space analysis of the past 25 years. Psychology, Public Policy, and Law, 16, 340-372. http://dx.doi.org/10.1037/a0020518 
Merriam, S. B. (2009). Qualitative research: A guide to design and implementation. San Francisco, CA: Jossey-Bass.

Mertens, D. M. (1998). Research methods in education and psychology: Interrating diversity with quantitative \& qualitative approaches.

Miles, M. B., \& Huberman, A. M. (1994). Qualitative data analysis: An expanded source book (2nd ed.). Thousand Oaks, Ca: Sage.

Milne, R., Poyser, S., Williamson, T., \& Savage, S. (2010). Miscarriages of justice: What can we learn? In J. Adler \& J. Gray (Eds.), Forensic psychology: Concepts, debates and practice (17-37). Cullompton, UK: Willan Publishing.

Myrick, F., \& Yonge, O. (2002). Preceptor questioning and student critical thinking. Journal of Professional Learning, 18(3), 176-181. doi: 10.1053/jpnu.2002.124485 National Higher Education Strategic Plan 2007-2020. Retrieved from: www. hu.ac.th/english/academic/documents/psptn2-eng.pdf

Nor Shidrah Mat Daud, Gilmore, A., \& Mayo, H. E. (2013). Exploring the potency of peer evaluation to develop critical thinking for tertiary academic writing. World Applied Sciences Journal 21 (Special Issue of Studies in Language Teaching and Learning), 109-116.

Noraini, Idris. (2007). The effect of Geometers' Sketchpad on the performance in Geometry of Malaysian students' achievement and van Hiele geometric thinking. Malaysian Journal of Mathematical Sciences, 1(2), 169 - 180.

Ng, L.Y., Bakar, K. A., Roslan , S., Wong, S. L., \& Rahman, P. Z. M. A. (2005). Predictors of self-regulated learning in Malaysian smart schools. International Educational Journal, 6(3), 343-353.

Otieno, V. R., Aloka, P. J. O, \& Odongo, B. C. (2015). Teachers' perceptions on oral questioning as a method of assessment of holistic development among Kenyan lower primary schools learners. Mediterranean Journal of Social Sciences, 6(3).

Othman, Nik Suryani Abd Rahman, Zainurin Abd Rahman, ... . Zainab Mohd Nor. (2014). Assessment for learning practices and competency among Malaysian university lecturers: A national study. Practitioner Research In Higher Education, 8(1), 14-31. 
Patton, M. Q. (1990). Qualitative evaluation and research methods (2nd ed.). Newbury Park, CA: Sage Publications.

Peterson, M. W., \& Einarson, M. K. (2001). What are colleges doing about student assessment? The Journal of Higher Education, 72(6), 629-669.

Petty, G. (1998). Teaching today: A practical guide (2nd ed.). Cheltenham, UK: Nelson Thornes

Radnor, H. (2001). Researching your professional practice. Buckingham, UK: Open University Press

Ramsden, P. (2003). Learning to teach in higher education (2nd ed.). London, UK: Routledge Falmer.

Robson, C. (2002). Read-world research (2nd ed.). Oxford, UK: Blackwell.

Rohaya Talib, Mohd Zaki Kamsah, Hamimah Abu Naim, \& Adibah Abdul Latif. (2014). From principle to practice: Assessment for learning in Malaysian school-based assessment classroom. International Journal of Social Science \& Education, 4(4).

Rosenshine, B., Meister, C., \& Chapman, S. (1996). Teaching students to generate questions: A review of the intervention studies. Review of Educational Research, 66(2), 181-221. doi: 10.3102/00346543066002181

Sachdeva, A. K. (1996). Use of effective questioning to enhance the cognitive abilities of students. Journal of Cancer Educ., 11, 17-124.

Sadler, D. R. (1998) Formative assessment: Revisiting the territory. Assessment in Education, 5(1), 77-84. Scoboria, A., \& Fisico, S. (2013). Encouraging and clarifying 'don't know' responses enhances interview quality. Journal of Experimental Psychology: Applied, 19, 72-82. doi: 10.1037/a0032067

Slavin, R. E. (1983). When does cooperative learning increase student achievement? Psychological Bulletin, 94(3), 429-445.

Sambell, K., McDowell, L., \& Brown, S. (1997). But is it fair?: An exploratory study of student perceptions of the consequential validity of assessment. Studies in Educational Evaluation, 23(4), 349-371.

Sebba, J., Deakin, C. R., Yu, G., Lawson, H., \& Harlen, W. (2008). Systematic review of research evidence of the impact on students in secondary schools of self and peer assessment. Report in Research Evidence in Education Library. London: EPPI-Centre, Social Science Research Unit, Institute of Education. 
Sellappah, S., Hussey, T., Blackmore, A. M., \& McMurray, A. (1998). The use of questioning strategies by clinical teachers. Journal of Advanced Nursing, 28(1), 142-148. doi: 10.1046/j.1365-2648.1998.00776.x

Silverman, D. (2001). Methods for analysing talk, text, and interaction: Interpreting qualitative data (2nd ed.). London, UK: Sage.

Singha, K. G., Goswami, M., \& Bharali, R. K. (2012). Study of various problems faced by the students and teachers in learning \& teaching Mathematics and their suggestive measures. International Journal of Advanced Research in Management and Social Sciences.

Spiller, D. (2012). Assessment Matters: Self-Assessment and PeerAssessment. The University of Waikato.

Stiggins, R. (2005). Student-involved assessment for learning. Upper Saddle River, NJ: Prentice Hall.

Tong, S. Y. (2011). Exploring Students' Perception of and Reaction to Feedback in School-based Assessment. Malaysian Journal Of ELT Research, 7(2).

Topping, K. J., Campbell, J., Douglas, W., \& Smith, A. (2003). Cross--age peer tutoring in mathematics with seven and eeven years olds: Influence on mathematical vocabulary strategic dialogue and self concept. Education Research, 45, 287-308.

Topping, K. J., Kearney, m.m McGee, E., \& Pugh, J. (2004). Tutoring in mathematics: A generic method. Mentoring and Tutoring, 12 (3), 351-368.

Topping, K. J. (1996). The effectiveness of peer tutoring in further and higher education: A typology and review of the literature. Higher Education, 32, 321-345.

Tunku Ahmad, T. B., Ainol Madziah Zubairi, Mohd Burhan Ibrahim, Joharry Othman, Nik Suryani Abd Rahman, Zainurin Abd Rahman, ...Zainab Mohd Nor. (2014). Assessment for learning practices and competency among Malaysian university lecturers: A national study. Practitioner Research in Higher Education, 8(1), 14-31.

Tunku Mohani Tunku Mohtar. (2010). The use of alternative assessment to sustain Teaching and learning. Tanjung Malim, Malaysia: Penerbit Universiti Pendidikan Sultan Idris.

Weaver, M. (2006). Do students value feedback? Student perception of tutors' written responses. Assessment \& Evaluation in Higher Education, 31(3), 379-394. 
Yin, R. K. (20033b). Case study research: Design and methods (3rd ed.). Newbury Park, CA: Sage.

Zubairi, A. M., Sarudin, I., \& Nordin, M. S. (2008). Faculty competency in assessment. The Annual Conference of the Association for Educational Assessment (IAEA), 7-12 September, Cambridge, UK. 
Appendices of the Study

\section{APPENDIX 1}

\section{Classroom Observation Protocol}

Instructions to observer: Please fill in all of the spaces below. Write your observational field notes on the same day as you conduct your observation. Discuss with your co-observer on the observation and write one consensus expanded field notes on the observed lesson. Submit both the soft and hard copies of the expanded field notes to the NRGS Project Secretariat (i.e. UERL) one week after the observation date. If possible, conduct an interview as soon as the observation ended for the purpose of clarification or seek permission to interview the participants (lecturers and students) at a later date, preferably within one week of the observation date.

\section{PART 1: BACKGROUND INFORMATION}

\begin{tabular}{|c|c|c|c|}
\hline \multicolumn{4}{|l|}{$\begin{array}{l}\text { Observer (s): } \\
\text { i. } \\
\text { ii. } \\
\text { iii. } \\
\text { iv. }\end{array}$} \\
\hline \multicolumn{2}{|c|}{ Observation Date: 1/10/2014 } & \multicolumn{2}{|c|}{ Observation Start Time: 10.00 a.m } \\
\hline \multicolumn{2}{|c|}{$\begin{array}{l}\text { Length of the Observation (Minutes): } 110 \\
\text { minutes }\end{array}$} & \multicolumn{2}{|c|}{ Observation End Time: 11.50 a.m } \\
\hline \multicolumn{4}{|l|}{ Venue: DK M } \\
\hline \multicolumn{2}{|l|}{ Lecturer's Name: } & \multicolumn{2}{|l|}{ Programme: } \\
\hline \multicolumn{2}{|l|}{ Course: } & \multicolumn{2}{|l|}{ Topic: } \\
\hline \multirow[t]{2}{*}{ Number of Students: 47} & Semester 1 & Other Semesters & Total \\
\hline & & & $\begin{array}{l}\text { Average } \\
\text { Student Age }\end{array}$ \\
\hline $\begin{array}{l}\text { Teaching Plan } \\
\text { (A request for the } \\
\text { information below will } \\
\text { be emailed to lecturers } \\
\text { before the observation } \\
\text { date. You can include the } \\
\text { informationhere) }\end{array}$ & \multicolumn{3}{|c|}{$\begin{array}{l}\text { a. i. Konsep akhlak dalam Islam (kognitif). } \\
\text { ii. Faham dan sedar kepentingan dan cara } \\
\text { berakhlak sesama manusia dan makhluk. } \\
\text { b. Guna PowerPoint dan klip video } \\
\text { c. i. Komunikasi } \\
\text { ii. Kemahiran berfikir/Penyelesaian Masalah } \\
\text { d. Akhlak mazmumah dan mahmudah }\end{array}$} \\
\hline
\end{tabular}


a. What are the learning outcomes the lecturer is hoping students to achieve?

b. What is the lecturer planning to do in order to achieve the LO (method) technique of delivery and assessment)?

c. What soft skills does the lecturer plan to incorporate in the lesson?

d. How does the lesson/ activity fit in with the topic that the class has been doing before?

Physical Arrangement: Dewan kuliah Draw or describe the physical arrangement of the classroom.

Technology and Resources: Whiteboard, desktop computer, LCD Describe the technology and resources present in the classroom. Fixed resources, like desktop computers, projector, and lab equipment can be included in the diagram of the classroom above.

\section{PART 2: OBSERVATION NOTES}

\section{PART 2: OBSERVATION NOTES}

In this section, please take detailed notes as you observe classroom activities.

The following questions serve as guidelines for what you will document during the classroom observation. Your descriptions of all the classroom activities should include answers to the questions in 2.1-2.5. For each topic/question, please note what you observe in the left-hand column and use the right-hand column to note your hypotheses and conjunctures about what you think, particularly in the context of the Provisional Guiding Principles (PGP). 


\subsection{Structure of the Lesson}

Describe the structure of the lesson that you observe. What is happening in the classroom at the beginning, middle and end? What are the lecturer and the students doing?

\begin{tabular}{ll}
\hline \multicolumn{1}{c}{ Observational Notes } & \multicolumn{1}{c}{ Reflective Notes } \\
\hline 1. Start the class. & $\begin{array}{l}\text { Did not structure students } \\
\text { focus on aspects that they } \\
\text { 2. Review main topic from previous lesson. } \\
\text { Ask review question: }\end{array}$ \\
-“Ada berapa peringkat akhlak?"- Students & $\begin{array}{l}\text { should particular } \\
\text { answers as a whole group. }\end{array}$ \\
3. Introduce new topic by showing a video & \\
clip. & \\
4. Relate today's topic with previous lesson. \\
5. Questions relating the previous topic with \\
materials in the video.(5 minutes) \\
6. Lecture about today's topic "Adab Anak \\
dan Ibubapa/Etika Anak Soleh". (Start from \\
10.13 a.m until 10.53 a.m.). \\
7. Plays another video clip. (4 minutes). \\
8. Continue lecture. \\
9. Closure-summarize the lesson and relate \\
with the next topic.
\end{tabular}

\subsection{Interactions between the Lecturer and Students}

How do the lecturer and students interact? Give examples of the type of questions the lecturer ask students and how students respond, as well as the questions the students ask the lecturer and the lecturer's responses. In addition to questions, please also note the other ways in which the lecturer and the students interact.

\begin{tabular}{ll}
\hline \multicolumn{1}{c}{ Observational Notes } & \multicolumn{2}{c}{ Reflective Notes } \\
\hline Review: & Beri pandangan tentang suasana \\
- A lot of Q\&A about 'Sabar'. & atau akhlak kejiranan yang anda \\
- Ask questions about how the hadapi sekarang? Apa sepatutnya \\
topic is related to the video dilakukan?(verbal questions) \\
shown. & - Not prepared on slide. \\
& - Setiap orang memberi pandangan. \\
\hline
\end{tabular}




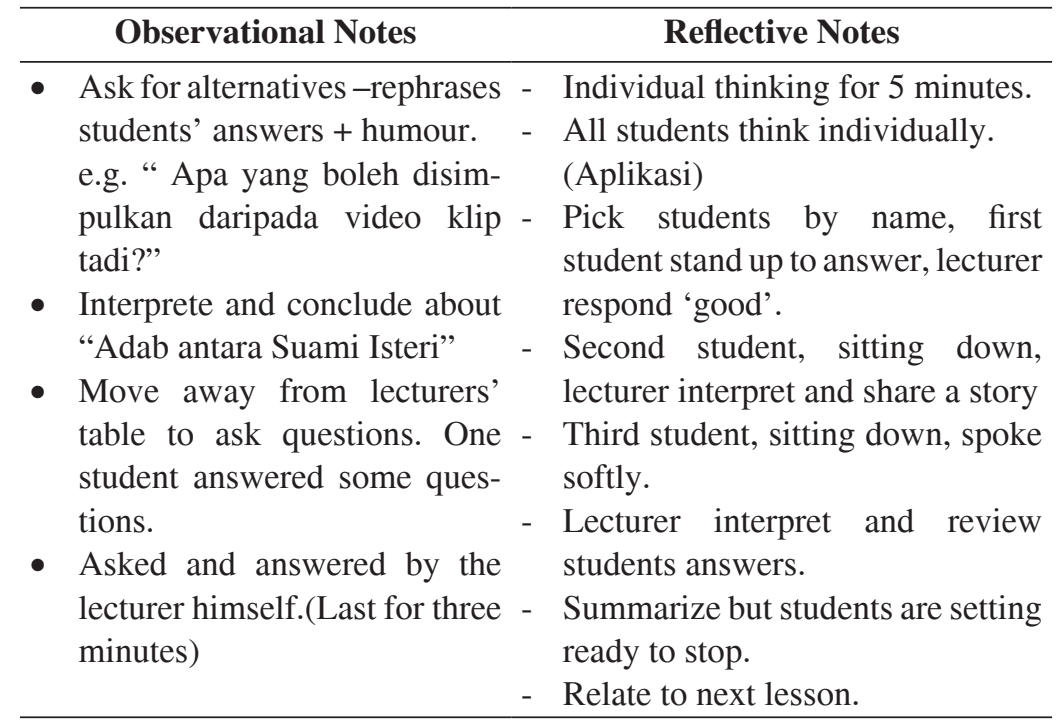

\subsection{Interactions among Students}

Do students have an opportunity to interact with one another? If so, how do they interact? Do they work on a task together? Do they provide feedback to one another?

\begin{tabular}{|l|l|}
\hline Observational Notes & Reflective Notes \\
\hline & \\
\hline
\end{tabular}

\subsection{Use of the Technology/Device/Resources}

Are the technology/device/resources being used as part of the activity? If so, how and for what purpose? Is the lecturer or students experiencing difficulties in their use of the technology/device/ resources? Are they able to troubleshoot? What other resources/ devices does the lecturer use? (e.g., chart paper, whiteboard, visual aids, computers, lab equipment etc.).

\begin{tabular}{|c|c|}
\hline Observational Notes & Reflective Notes \\
\hline Use video clips from Maher Zain and Movie "Up". & \\
\hline
\end{tabular}




\subsection{Other Observations}

What else do the lecturer and students do?

\begin{tabular}{|c|c|}
\hline Observational Notes & Reflective Notes \\
\hline -students were not encouraged to ask questions. & \\
& \\
\hline
\end{tabular}

Appendix 2 (Pre-observation form)
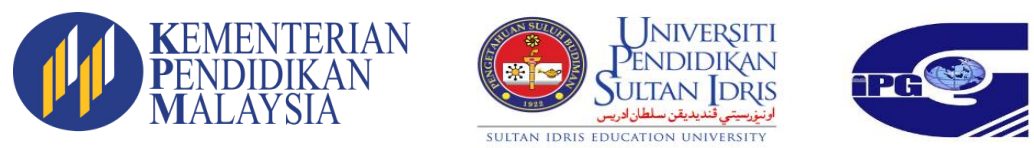

\section{Development of a Teacher Education Model for Preparing} Quality teachers for the Future

\section{Maklumat Pra-Pemerhatian}

ARAHAN: Borang ini bertujuan mengumpul maklumat tentang perancangan pengajaran pensyarah. Sila respon kepada semua item. Respon anda dalam tinjauan ini adalah sulit dan akan digunakan untuk tujuan yang berkaitan dengan kajian ini sahaja.

1. Nama:

2. Jawatan:

3. Gelaran:

4. Institusi:

5. Pengalaman mengajar:

\begin{tabular}{|l|l|}
\hline & $<1$ tahun \\
$1-5$ tahun \\
$6-10$ tahun \\
\cline { 1 - 2 } & $11-15$ tahun \\
$16-20$ tahun \\
$21-30$ tahun
\end{tabular}

